\title{
The Safe Haven Property of Gold in Turkish Financial Markets: An Investigation of the Global Financial Crisis
}

\author{
Gaye Gencer* \\ Yeditepe University
}

\author{
ZaferMusoğlu** \\ Yeditepe University
}

\begin{abstract}
This paper investigates whether gold acts as a safe haven, a hedge or a diversifier for stocks and bonds in Turkey. We employ the dynamic conditional correlation (DCC-GARCH) model which is a class of multivariate generalized autoregressive conditional heteroskedastic (GARCH) models. DCC-GARCH has two steps; the first step models the volatility dynamics in a univariate context and the second step involves computing dynamic correlations. We use daily data from June 2006 to November 2013, a period witnessing the most recent global financial crisis and its aftermath. Our univariate GARCH model results reveal that current volatility is conditional on past shocks and volatilities for gold, stocks and bonds in Turkey. In this study, we hypothesize that gold is a hedge if the gold and the asset class are uncorrelated or negatively correlated on average, while it is a safe haven if the correlations are negative in times of market stress. The second step analyses show that gold acts as a hedge on average and a safe haven during equity market downturns for stocks. Across bonds, we show that gold acts as a hedge on the average, however it is not a safe haven during turmoil periods. Our results are of significance for portfolio managers, international investors and policy makers.
\end{abstract}

Keywords: DCC-GARCH, gold, safe haven, stocks, bonds.

\section{Türk Finansal Piyasalarında Güvenli Liman olarak Altın: Global Finansal Kriz Üzerine Bir Araştırma}

\section{Özet}

Bu çalışma, altının Türkiye'de hisse senedi ve devlet tahvili yatırımlarına karşı güvenli liman, hedge ve yatırım çeşitlendirmesi özelliğini araştırmaktadır. Bu araştırmada, GARCHÇok Değişkenli Genel Gözleme Dayalı Koşullu Modellerin bir sınıfı olan DCC-GARCHDinamik Koşullu Bağlantı modeli kullanılmıştır. DCC-GARCH modeli iki aşamalıdır; ilk aşama, değişkenlik dinamiklerini tek değişkenli bağlamda değerlendirirken, ikinci aşamada dinamik korelasyonlar hesaplanır. Çalışmada, son yaşanan küresel finansal kriz ve sonrasını kapsayan Haziran 2006 ile Kasım 2013 arasındaki günlük veriler kullanılmıştır.

\footnotetext{
* Gaye Gencer is an Assistant Professor in the Department of Business Adminisration at Yeditepe University, Kayışdağ1, İstanbul, Turkey. E-mail: gaye70@yahoo.com,

** Zafer Musoğlu is a PhD student in the Department of Business Adminisration at Yeditepe University, Kayışdağı, İstanbul, Turkey. E-mail:zmusoglu@pbs.com.tr
} 
Tek değişkenli GARCH model sonuçları, tüm değişkenlerde mevcut oynaklığın geçmiş şoklara ve oynaklığa bağlı olduğunu açığa çıkarmıştır. Bu araştırmada, genel olarak, altın ve diğer menkul kıymet arasındaki korelasyon katsayısı eksi işaretliyse veya istatistiksel olarak anlamlı değilse, altının hedge özelliği gösterdiği varsayılmıştır. Finansal piyasaların çalkantılı olduğu dönemlerde, altın ve diğer menkul kıymet arasındaki negatif korelasyon ise altının güvenli liman özelliğini işaret etmektedir. Çalışmanın ikinci aşaması, altının hisse senedi piyasalarına karşı genel olarak hedge özelliği gösterdiğini, kriz zamanlarındaysa hisse senedi yatırımlarına karşı güvenli liman olarak görüldügüüü meydana çıkarmıştır. Altın, devlet tahvillerine karşı genel olarak hedge özelliği göstermekle beraber, piyasaların çalkantılı olduğu dönemlerde güvenli liman özelliğini sergilememektedir. Bu araştırma, portföy yöneticileri, uluslararası yatırımcılar ve karar alıcılar için anlamlı sonuçlar içermektedir.

Anahtar kelimeler: DCC-GARCH, altın, güvenli liman, hisse senedi, tahvil.

$\mathrm{T}$

The global financial markets have suffered from severe turmoil especially in the last two decades as the result of the increased financial liberalization and economic integration. As a remedy, the debates on financial contagion focus on redesigning portfolios away from stocks and bonds to incorporate safer investments such as gold. Gold is a unique asset which serves as a hedge or even a safe haven in times of financial distress. Capie et al. (2005) assert that gold is a hedge since it has been the basis of the monetary system (gold standard) for a considerably long part of the recorded past. Baur and Lucey (2010) define a hedge as an asset that is on average uncorrelated or negatively correlated with another asset or portfolio. They note that a hedge may not reduce the losses at times of extreme market downturns because the asset may exhibit positive correlations with other assets sometimes, and negative correlations other times, resulting in a negative correlation on the average. On the other hand, a safe haven may be negatively correlated or uncorrelated with another asset or portfolio at times of extreme market declines. A safe haven has the potential to compensate for the losses at times of severe market distress. Baur and Lucey (2010) further distinguish a diversifier on average as an asset that is positively though not perfectly correlated, with another asset. Thus, a diversifier lacks the potential of reducing losses.

Gold as a financial asset has been the focus of vast academic research. Most of the previous literature pivots on the relation between gold and some selected economic variables. Lawrence (2003) investigates whether gold returns are correlated with economic activity, financial assets and other commodities. He documents no significant correlation between gold returns and change in macroeconomic variables. Furthermore, he alleges that gold returns are less correlated with equity and bond returns than other commodities' returns. Tully and Lucey (2007) conclude that the US dollar is the major determinant for gold returns. Capie et al. (2005) evidence the hedging quality of gold against the dollar while Sherman (1982); Baker and Van-Tassel (1985); Kaufmann and Winters (1989); Sjaastad and Scacciavillani (1996); McCown and Zimmerman (2006); Worthington and Pahlavani (2007); Wang et al. (2011); Beckmann and Czudaj (2013) adduce the inflation-hedging trait of gold. Kutan and Aksoy (2004) contrarily document 
that gold does not carry the inflation hedging quality in Turkey. There is also a strand of literature examining the relation between gold prices and interest rates. Koutsoyiannis (1983); Fortune (1988); Cai et al. (2001) all document a strong bound between interest rates and gold prices.

A second line of literature aims to measure the performance of gold investments against other financial assets. The role of gold investments as a portfolio diversifier is confirmed by a number of scholars in different markets (Michaud et al.,2006; Hillier et al., 2006; Barisheff, 2006; Conover et al., 2007; Wozniak, 2008; Ratner and Klein, 2008; Hoang, 2011; Ibrahim and Baharom, 2011). Some of these studies analyze both physical gold and paper gold (gold-mining company stocks or gold mutual funds) as portfolio diversifiers (McDonald and Solnik, 1977; Jaffe, 1989; Chua et al., 1990; Blose, 1996; Faff and Chan, 1998; Hoang, 2011) to verrify the fact that physical gold is more efficient than paper gold. One of the pioneering studies was conducted by McDonald and Solnik (1977) who analyze the relation among gold prices, gold mining stocks and the S\&P 500 index between 1948 and 1975. Their results reveal that gold returns and the S\&P 500 index are not related while gold mining stock returns and gold returns are positively related. Jaffe (1989) shows that gold returns have weak correlations with both stock and bond returns, and gold investments lower the portfolio risk. Smith (2001) analyzes the relation between four gold prices and six US stock indices (the Dow Jones Industrial Average, the NASDAQ Composite, the NYSE Composite, the S\&P 500, the Russell 3000 Index, and the Wilshire 5000 Equity Index) between 1991 and 2001. He reports unidirectional causality from US stock returns to gold returns along with negative and small short-run correlations in-between. Smith (2002) expands his analysis to cover 18 stock indices (Austria, Belgium, Denmark, Finland, France, Germany, Greece, Ireland, Italy, Japan, Netherlands, Norway, Portugal, Spain, Sweden, Switzerland, Turkey, United Kingdom) in a further study documenting results similar to his previous work.

More recently, Morales (2008) has studied a sample of G7 countries' stock markets (Canada, France, Germany, Italy, Japan, UK and US) between 1995 and 2006 by applying the EGARCH analysis. He avers significant volatility persistence from precious metals' returns, including gold, platinum and silver to stock returns. Gilmore et al. (2009) explicate the dynamic relationships between gold prices, gold mining companies' stocks and stock market indices. Their results manifest a long-term relation between gold and large-cap stock prices, and a short-term unidirectional causality running from largecap stocks to those of gold mining companies and from there to gold prices. Baur and McDermott (2010) work on a sample of 53 international stock markets between 1979 and 2009. They conclude that at times of crisis gold acts as both a strong safe haven and a hedge for most developed markets, especially the European and the US markets, but not in Japan, Canada, Australia and the BRIC countries. Baur and Lucey (2010) come up with similar results in German, UK and US markets on a data sample ranging from 1995 to 2005. The authors substantiate the findings that gold is a safe haven for stocks in all three markets only after severe market declines, and for a limited time of about fifteen trading days. They also validate the hedging quality of gold for the US and UK stock markets. Their results indicate that gold is not a safe haven for bonds, but a hedge 
only in the US and UK bond markets. Likewise, Hood and Malik (2013) ascertain the gold possessing hedge and weak safe haven properties in the case of the US stock market for the period between 1995 and 2010. Sumner et al. (2010) analyze the volatility spillovers among gold prices, stock and bond markets in the US for the sample period between 1970 and 2009. They adduce a low and slightly negative correlation between gold and both stock and bond market returns. However, they do not report significant volatility spillovers between gold-stock or gold-bond markets.

Moreover, there is also literature focusing on the relation between gold investments and the stock markets of emerging and developing economies. Mishra et al. (2010) corroborate a bi-directional causality between gold prices and the Indian stock market over a period from 1991 to 2009. Ziaei (2012) deduces that gold acts as a hedge but not a safe haven in the ASEAN+3 countries (China, Japan, Indonesia, Malaysia, the Philippines, Singapore, South Korea, and Thailand). Jaiswal and Voronina (2011) analyze the role of gold investments in the BRIC (Brasil, Russia, India, and China) economies between 2001 and 2010, and acknowledge gold as a hedge and diversifier in these markets, though at varying strengths.

This paper attempts to measure the time-varying correlations between gold investments, stocks and bonds in Turkey between June 2006 and November 2013, in an effort to examine the hedge and safe haven properties of gold during the most recent global financial crisis. Our sample period witnesses the global financial crisis, marked by the collapse of the Lehman Brothers and its aftermath. In Turkey, gold has held a traditional place as a secure investment asset for many generations. According to the World Gold Council reports (April 2013), Turkey ranks as the $15^{\text {th }}$ economy in the world, with her 375.7 tons of gold reserves. Furthermore, this study aims to assess gold as a quality asset in accord with the flight-to-quality literature. In times of increased uncertainty, investors prefer to hold average-risk portfolios, a phenomenon called flight-to-quality (Hartmann et al., 2001; Connolly et al., 2005; Baur and Lucey, 2006). The flight-to-quality literature mainly concentrates on stocks' fleeing to bonds at times of equity market turbulence as a mechanism to curtail losses. Flight to more quality assets at times of financial distress helps the financial system to maintain stability even in adverse conditions. The flight to gold from either stock investments or bond investments at times of market turmoil is a sign that gold is regarded as a quality asset among investors, and that it is used as a valve to control losses in designing portfolios. Our study investigates the safe haven and hedge properties of gold for Turkish financial markets, employing a DCC-GARCH framework, a novel technique for assessing the time-varying conditional correlations. The rest of the paper is organized as follows: Part 2 describes the methodology applied; Part 3 defines the data; Part 4 discusses the findings; and finally Part 5 concludes our study.

\section{Methodology}

A Dynamic Conditional Correlation (DCC) model provides a generalization of the Constant Conditional Correlation model by Bollorslev (1990). In the earlier studies, it is assumed that correlations are constant among variables. However as suggested by 
Longin and Solnik (1995), the assumption of "constant correlations among variables in equity markets" does not hold over time. As an expedient, in order to measure timevarying correlations, Engle (2002) proposes the dynamic conditional correlations (DCC) model, providing an extra two parameters which are used to evaluate the effects of past innovations and past correlations on the current conditional correlations. A Constant Conditional Correlation (CCC) model can be written as follows:

$$
H_{t}=D_{t} R D_{t}
$$

where $\mathrm{R}$ represents constant conditional correlation matrix and $\mathrm{D}_{\mathrm{t}}=\operatorname{diag}\left(\sigma_{1 \mathrm{t}}, \sigma_{2 t}, \ldots, \sigma_{\mathrm{Nt})}\right.$. The Dynamic Conditional Correlation (DCC) model can be described as follows:

$$
H_{t}=D_{t} R_{t} D_{t}
$$

where $R_{t}$ is the time varying correlation matrix and $D_{t}$ is the diagonal matrix of time varying standard deviations from univariate $\mathrm{GARCH}$ model in each series.

The elements of matrix $\mathrm{D}_{\mathrm{t}}$ are given by the univariate $\mathrm{GARCH}(\mathrm{p}, \mathrm{q})$ model (Engle and Sheppard, 2001):

$$
h_{i t}=\omega_{i}+\sum_{p=1}^{P_{i}} \alpha_{i p} r_{i t-p}^{2}+\sum_{q=1}^{Q_{i}} \beta_{i q} h_{i t-q}
$$

where $h_{i t}$ and $h_{i t-q}$ denote the conditional variances at time $t$ and $t-q$, respectively, while $r_{i t-p}$ represents the past shocks.

Dynamic correlation is computed by the equations below:

$$
\begin{aligned}
& Q_{t}=\left(1-\sum_{m=1}^{M} \alpha_{m}-\sum_{n=1}^{N} \beta_{n}\right) Q^{-}+\sum_{m=1}^{M} \alpha_{m}\left(\varepsilon_{t-m} \varepsilon_{t-m}^{\prime}\right)+\sum_{n=1}^{N} \beta_{n} Q_{t-n} \\
& R_{t}=Q_{t}^{*-1} Q_{t} Q_{t}^{*-1}
\end{aligned}
$$

where $M$ is the length of the innovation term in the DCC estimator, and $N$ is the length of the lagged correlation matrices in the DCC estimator. $Q$ is the unconditional covariance of the standardized residuals resulting from the first stage estimation and $Q_{t}^{*}$ is a diagonal matrix composed of the square root of the diagonal elements of $Q_{t}$. The lagged GARCH standardized residual obtained from the first step estimation is $\varepsilon_{t-m}$, and $\varepsilon_{t-m}^{\prime}$ is its transpose.

The log likelihood of the estimator is:

$$
L=(-1 / 2) \sum_{t=1}^{T}\left(k \log (2 \pi)+2 \log \left(\left|D_{t}\right|\right)+\log \left(\left|R_{t}\right|\right)+\varepsilon^{\prime} R_{t}^{-1} \varepsilon_{t}\right)
$$

where $\varepsilon_{t}$ is the residual which is normally distributed with a zero mean and a time varying variance, and is standardized by the conditional standard deviation.

In modeling the DCC-GARCH model, we assume conditional probability distribution density function of error terms which follow normal distribution, and the model is estimated with the Quasi Maximum Likelihood (QMLE) method. In addition, we use the BHHH (Berndt, Hall, Hall and Hausman) iterative algorithm to obtain the optimal values of the parameters. This algorithm is employed in many of the papers in the field. 
In addition, Bollorslev et al. (1992) agree that a $\operatorname{GARCH}(1,1)$ specification with lag length one is adequate to capture the dynamics of conditional variance. We examine several lags of the model comparing the information criteria for each (Akaike, Scwartz, Hannan-Quinn). Our results also support the assumption of Bollorslev.

\section{Data Analysis}

For this study, we use daily data over the period from June 6, 2006 to November 29, 2013. The data set includes gold prices per troy ounce announced by the Istanbul Gold Exchange (IGE), by closing prices of the Istanbul Bourse composite index (BIST100) and the 10-year government bond prices. All price data is denominated in Turkish Liras. We take the gold prices and the stock market composite index (BIST100) from the Istanbul Bourse and the 10-year government bond prices from Bloomberg. ${ }^{[1]}$ The return series can be obtained as follows:

$$
R_{t}=\ln \left(P_{t} / P_{t-1}\right)
$$

where $\mathrm{R}_{\mathrm{t}}$, denotes return, $\mathrm{P}_{\mathrm{t}}$ and $\mathrm{P}_{\mathrm{t}-1}$ represent price at time $\mathrm{t}$ and price at time $\mathrm{t}-1$, respectively.

Table 1 presents the summary statistics of the return variables. The mean values of the returns are $0.05 \%, 0.04 \%$ and $0.07 \%$ for bonds, stocks and gold, respectively, while the standard deviations are 1.65, 2.07, and 1.48 in the same order. In Turkey, gold investments yield the highest return at the lowest risk measured in terms of standard deviation, while bond returns are very slightly negative, and stock returns are considerably lower and carry a much higher risk compared to gold. Moreover, excess kurtosis is computed for all the return variables (greater than 3), implying a non-normal distribution. The non-normality is also confirmed by the rejection of the Jarque-Bera test statistics' null hypothesis. Typically, Ljung-Box tests up to the 10th lag indicate serial correlations on raw and squared data. The ARCH (10) test results reveal that the variables contain significant ARCH effects. Finally, the Augmented-Dickey-Fuller (ADF) test applied to the return variables provides the rejection of unit-roots. Therefore, the return data is in consonance for GARCH-type modeling and further analysis.

Figure 1 presents the log-difference plot of the IGE, BIST 100 and 10-year government bond prices. Beginning by mid-2007, it can be seen that the returns in gold and stocks are highly volatile for about two years until mid-2009, a period marked by the sub-prime mortgage crisis in the world. From the graphs, it is evident that volatility clustering exists for all of the variables, highlighting the GARCH-class models for further volatility and dynamic correlation analysis.

\footnotetext{
[1] Bloomberg data service provides adjusted and generic price data for the 10-year government bond indices of a variety of countries which are widely used in academic studies. To analyze the safe haven property of gold against bond investments, long-term (10-year) government bond returns are used in literature. The price of longer maturity bonds are affected more than shorter maturity bonds, relevant to a change in the market interest rates, which is defined as the interest rate price risk.
} 
Table 1

Descriptive Statistics (\%)

\begin{tabular}{lccc}
\hline & Gold & BIST100 & Bond \\
\hline Mean & 0.075 & 0.044 & -0.050 \\
\hline Minimum & -9.258 & -14.65 & -9.255 \\
\hline Std. Dev. & 8.376 & 10.553 & 11.269 \\
\hline Skew. & 1.650 & 2.073 & 1.484 \\
\hline Kurt. & 0.079 & -0.732 & 0.559 \\
\hline J-B & 4.720 & 6.845 & 7.322 \\
\hline ARCH (10) & $1527.3^{\mathrm{a}}$ & $3355.1^{\mathrm{a}}$ & $3619.7^{\mathrm{a}}$ \\
\hline & $(0.000)$ & $(0.000)$ & $(0.000)$ \\
\hline Q (10) & $(0.000)$ & $18.742^{\mathrm{a}}$ & $21.699^{\mathrm{a}}$ \\
\hline Q2 (10) & $37.364^{\mathrm{a}}$ & $43.131^{\mathrm{a}}$ & $34.348^{\mathrm{a}}$ \\
\hline & $(0.000)$ & $(0.000)$ & $(0.000)$ \\
\hline ADF & $418.979^{\mathrm{a}}$ & $345.220^{\mathrm{a}}$ & $387.000^{\mathrm{a}}$ \\
\hline & $(0.000)$ & $(0.000)$ & $(0.000)$ \\
\hline & $-24.837^{\mathrm{a}}$ & $-23.647^{\mathrm{a}}$ & $-20.805^{\mathrm{a}}$ \\
\hline & $(0.000)$ & $(0.000)$ & $(0.000)$ \\
\hline
\end{tabular}

Notes: (a) denotes the statistical significance at the $1 \%$ level.

Figure 1

\section{Return Plots}
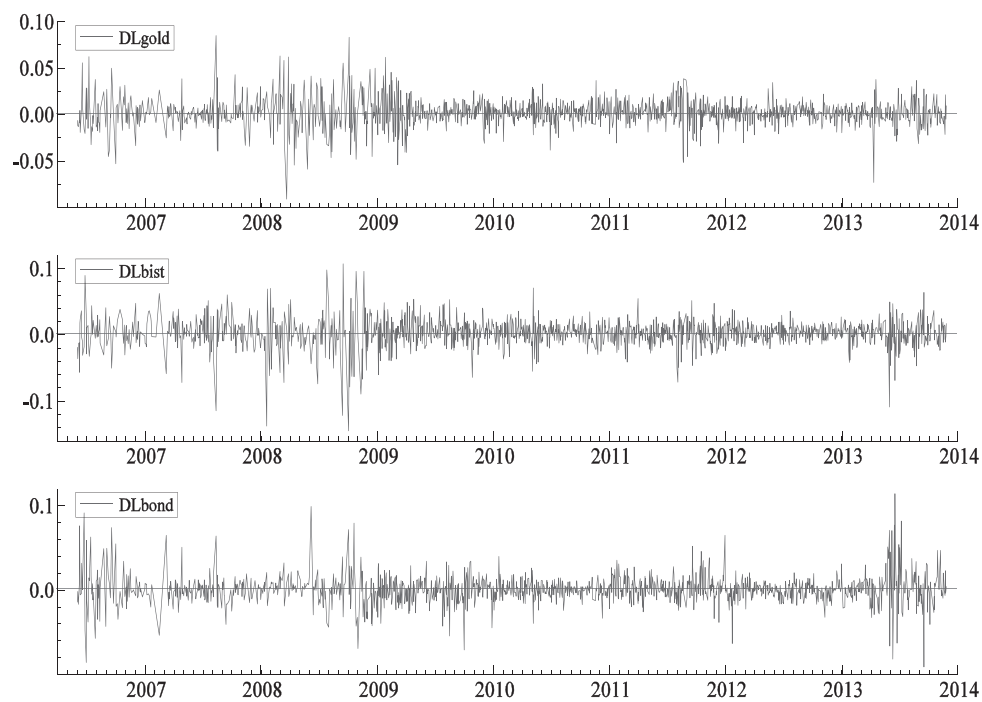


\section{Empirical Results}

In this section, we discuss the empirical results of the dynamic correlations between the pairs of gold-stocks and gold-bonds. For the analyses, apart from our models for the whole sample period, we also use two sub-samples for investigating the hedge and safe haven properties of gold. The time span of the first sub-sample is from March 13, 2007 to August 12, 2009 and it witnesses the global financial crisis marked by the collapse of Lehman Brothers. The second sub sample is from January 4, 2010 to November 29, 2013 and it represents the post-crisis episode.

Table 2

DCC $(1,1)$ Model Results for the Gold-Stocks Pair

\begin{tabular}{|c|c|c|c|c|c|c|}
\hline & Whol & ample & Crisi & eriod & Post-c & s Period \\
\hline & Gold & BIST 100 & Gold & BIST 100 & Gold & BIST 100 \\
\hline $\mathrm{C}(\mathrm{M})$ & $0.000^{c}$ & $0.001^{\mathrm{a}}$ & 0.000 & $0.002^{b}$ & 0.039 & $0.135^{\mathrm{a}}$ \\
\hline & $(0.061)$ & $(0.000)$ & $(0.709)$ & $(0.027)$ & $(0.212)$ & $(0.003)$ \\
\hline$C(V)$ & $0.059^{\mathrm{b}}$ & $0.097^{b}$ & 0.054 & $0.690^{c}$ & 0.130 & $0.132^{\mathrm{b}}$ \\
\hline & $(0.010)$ & $(0.043)$ & $(0.278)$ & $(0.080)$ & $(0.177)$ & $(0.021)$ \\
\hline$\alpha$ & $0.141^{\mathrm{a}}$ & $0.129^{\mathrm{a}}$ & $0.206^{\mathrm{b}}$ & $0.231^{\mathrm{c}}$ & $0.124^{b}$ & $0.127^{\mathrm{a}}$ \\
\hline & $(0.000)$ & $(0.002)$ & $(0.011)$ & $(0.065)$ & $(0.060)$ & $(0.004)$ \\
\hline$\beta$ & $0.837^{\mathrm{a}}$ & $0.856^{\mathrm{a}}$ & $0.813^{\mathrm{a}}$ & $0.702^{\mathrm{a}}$ & $0.769^{\mathrm{a}}$ & $0.823^{\mathrm{a}}$ \\
\hline & $(0.000)$ & $(0.000)$ & $(0.000)$ & $(0.000)$ & $(0.000)$ & $(0.000)$ \\
\hline DCC parameter & & & & & & \\
\hline$\rho$ & $-0.118^{c}$ & & $-0.380^{\mathrm{a}}$ & & -0.050 & \\
\hline & $(0.080)$ & & $(0.000)$ & & $(0.232)$ & \\
\hline$\alpha$ & 0.030 & & 0.0112 & & 0.054 & \\
\hline & $(0.156)$ & & $(0.487)$ & & $(0.151)$ & \\
\hline$\beta$ & $0.945^{\mathrm{a}}$ & & $0.945^{\mathrm{a}}$ & & 0.392 & \\
\hline & $(0.000)$ & & $(0.000)$ & & $(0.195)$ & \\
\hline Univariate Diag & & & & & & \\
\hline$Q^{2}(10)$ & 5.250 & 3.740 & 3.435 & 2.582 & 4.036 & 6.252 \\
\hline & $(0.873)$ & $(0.958)$ & $(0.969)$ & $(0.989)$ & $(0.945)$ & $(0.793)$ \\
\hline Multivariate Dia & & & & & & \\
\hline Hosking (10) & 31.254 & & 23.046 & & 22.201 & \\
\hline & $(0.772)$ & & (0.973) & & $(0.980)$ & \\
\hline Li-McLeod (10) & 31.271 & & 23.243 & & 22.288 & \\
\hline & $(0.771)$ & & $(0.971)$ & & $(0.980)$ & \\
\hline
\end{tabular}

Notes: (a), (b) and (c) denote the statistical significance at the 1\%, 5\% and 10\% levels. 
In table 2, we document the results of our DCC GARCH $(1,1)$ models. The full sample period is investigated to elicit the role of gold as a hedge or a diversifier on average. The tabulated results denote that the parameters of the past shocks $(\alpha)$ and past volatilities $(\beta)$ impact current conditional volatility in the univariate context, since they are both statistically significant at the $1 \%$ level. The dynamic correlation coefficient ( $\rho$ ) is -0.118 , and it is significant at the $10 \%$ level. As a hedge is either uncorrelated or negatively correlated with other assets in general, this result brings the conclusion that gold is a hedge across stocks on average in Turkey.

The crisis sub-sample analysis implies that the univariate parameters, $\alpha$ and $\beta$ are statistically significant, substantiating the effect of past shocks and volatilities on the current conditional volatility. The dynamic conditional correlation between gold and stocks is -0.380 , significant at the $1 \%$ level, educing that gold is a safe haven for stocks in times of market distress. As postulated by Baur and Lucey (2010), a safe haven compensates the investors for trading losses as its price rises in adverse market conditions when the prices of the other assets fall. The flight from stocks to gold investments can be deduced from the above finding, placing gold as a quality asset in Turkish financial markets.

The findings of the post-crisis period demonstrate that the correlation coefficient is not statistically significant. This result supports the previous findings related to the association between gold and stocks in Turkey. Thus, gold acts both as a hedge in general and a safe haven in the extreme market conditions across the equity market.

Table 2 also documents the univariate and multivariate test results applied, as diagnostic checks to standardized squared residuals. The univariate tests of Ljung-Box Q (10) results show no serial correlations in the squared residuals. In addition, the Hosking and Li- McLeod multivariate portmanteau tests, the extensions of the univariate LjungBox test, are applied to the squared residuals. The associated test results posit that the fitted multivariate model is adequate to obtain the reliable parameters.

The above findings can be seen as visual representations in Figure 2. The first graph represents the time varying evolution of conditional correlations during the whole period. From the graph, it is evident that the negative correlations are strongest during the crisis period. The other two graphs are for the crisis and post-crisis periods, illustrating the above findings.

In Table 3, we present the DCC-GARCH $(1,1)$ model results for the gold-bonds pair. All of the past shocks and volatility coefficients are statistically significant, except for the past shock parameter of bonds in the crisis period. The whole sample period analysis indicates that the dynamic conditional correlation parameter is found to be statistically insignificant, while the past conditional correlation impacts the current correlation with the lag of 1 . Therefore, gold is a hedge for bonds on average in Turkey. The dynamic correlation coefficient is positive $(0.377)$ and significant at the $1 \%$ level over the crisis period, implying that gold is not a safe haven asset across bonds during the crisis period because they move together when the diversification is needed most. We also document that the correlation coefficient is statistically insignificant in the post-crisis period, confirming the hedging property of gold against bonds. 
Figure 2

Plots of Time-varying Correlations between Gold and Stocks
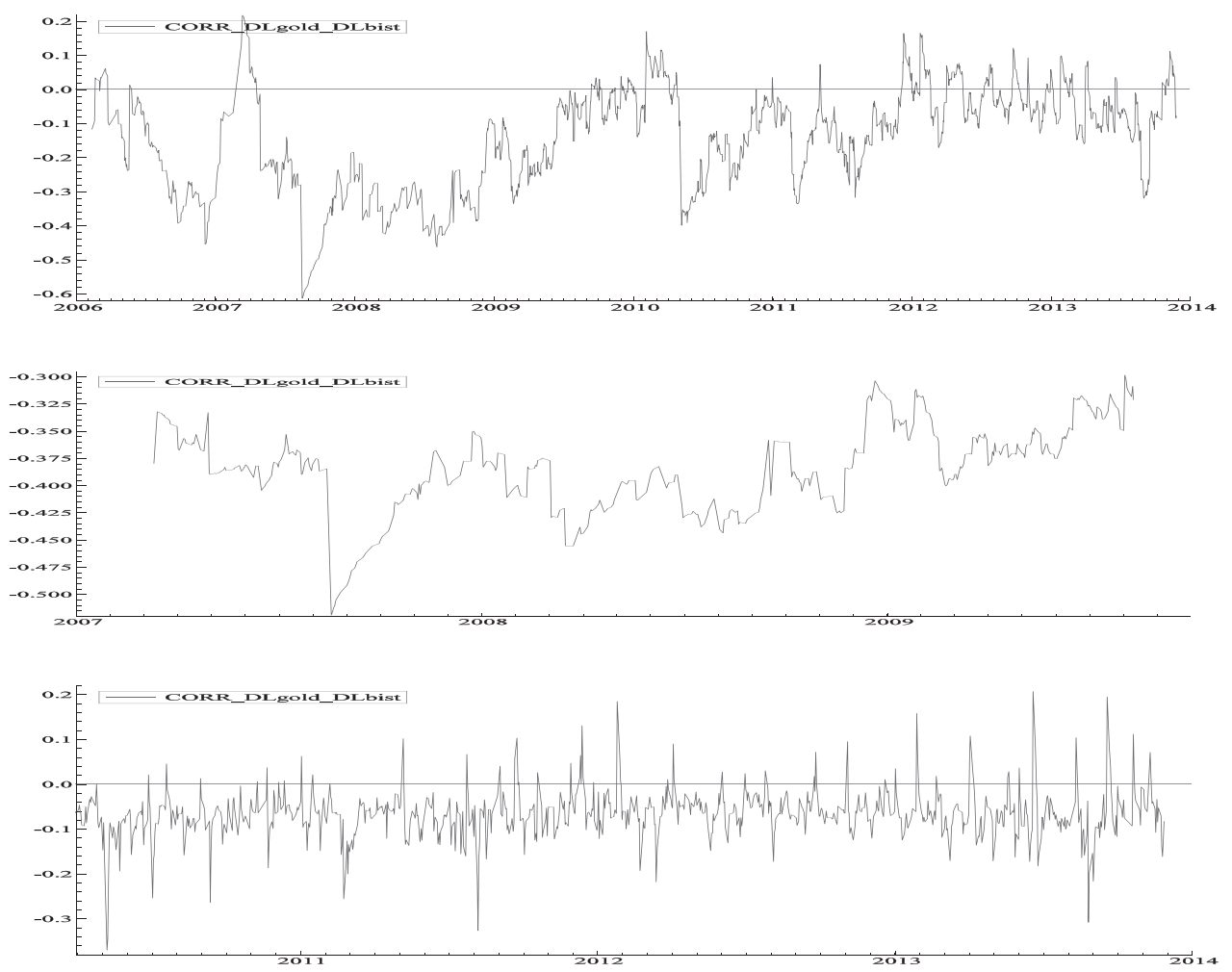

Table 3 also includes diagnostic tests for both univariate and multivariate models. Ljung-Box test statistics show that all the model residuals pass the test and have no autocorrelation. The multivariate tests, Hosking and Li-McLeod, verify that the fitted DCC $(1,1)$ model is empirically sufficient to capture the correlation dynamics.

Figure 3 represents the time-varying correlations between gold-bonds pair. Although the dynamic correlation parameter is statistically insignificant from the first graph, it is evident that correlations are mostly positive and highly volatile. The second graph displays the behavior of the correlation in the crisis period and depicts the correlations fluctuating in a band between 0.30 and 0.55 . From the plots we can draw the conclusion that gold is not a safe haven across bonds. The last graph demonstrates the post-crisis period where the correlations move in a narrower band around zero. 
Table 3

DCC $(1,1)$ Model Results for the Gold-Bonds Pair

\begin{tabular}{|c|c|c|c|c|c|c|}
\hline & \multicolumn{2}{|c|}{ Whole Sample } & \multicolumn{2}{|c|}{ Crisis Period } & \multicolumn{2}{|c|}{ Post-crisis Period } \\
\hline & Gold & Bond & Gold & Bond & Gold & Bond \\
\hline \multirow[t]{2}{*}{$\mathrm{C}(\mathrm{M})$} & $0.000^{\mathrm{b}}$ & $0.000^{\mathrm{a}}$ & 0.000 & $-0.001 c$ & 0.041 & $-0.096^{a}$ \\
\hline & $(0.074)$ & $(0.007)$ & $(0.675)$ & $(0.071)$ & $(0.218)$ & $(0.009)$ \\
\hline \multirow[t]{2}{*}{$\mathrm{C}(\mathrm{V})$} & $0.059^{b}$ & 0.056 & 0.051 & 0.175 & 0.167 & 0.019 \\
\hline & $(0.019)$ & $(0.133)$ & $(0.376)$ & $(0.611)$ & $(0.184)$ & $(0.167)$ \\
\hline \multirow[t]{2}{*}{$\alpha$} & $0.130^{\mathrm{a}}$ & $0.093^{\mathrm{b}}$ & $0.165^{\mathrm{b}}$ & 0.059 & $0.149^{c}$ & $0.082^{\mathrm{a}}$ \\
\hline & $(0.000)$ & $(0.012)$ & $(0.011)$ & $(0.579)$ & $(0.079)$ & $(0.000)$ \\
\hline \multirow[t]{2}{*}{$\boldsymbol{\beta}$} & $0.845^{\mathrm{a}}$ & $0.889^{\mathrm{a}}$ & $0.844^{\mathrm{a}}$ & $0.871^{\mathrm{a}}$ & $0.721^{\mathrm{a}}$ & $0.912^{\mathrm{a}}$ \\
\hline & $(0.000)$ & $(0.000)$ & $(0.000)$ & $(0.000)$ & $(0.000)$ & $(0.000)$ \\
\hline \multicolumn{7}{|l|}{ DCC parameters } \\
\hline \multirow[t]{2}{*}{$\rho$} & 0.073 & & $0.377^{\mathrm{a}}$ & & 0.039 & \\
\hline & $(0.362)$ & & $(0.000)$ & & $(0.377)$ & \\
\hline \multirow[t]{2}{*}{$\alpha$} & 0.016 & & 0.014 & & 0.032 & \\
\hline & $(0.125)$ & & $(0.516)$ & & $(0.156)$ & \\
\hline \multirow[t]{2}{*}{$\beta$} & $0.973^{\mathrm{a}}$ & & $0.880^{\mathrm{a}}$ & & $0.840^{\mathrm{a}}$ & \\
\hline & $(0.000)$ & & $(0.000)$ & & $(0.000)$ & \\
\hline \multicolumn{7}{|c|}{ Univariate Diagnostic } \\
\hline \multirow[t]{2}{*}{$Q^{2}(10)$} & 2.239 & 5.531 & 2.425 & 2.169 & 4.589 & 3.893 \\
\hline & [0.994] & {$[0.852]$} & [0.991] & [0.994] & {$[0.916]$} & {$[0.952]$} \\
\hline \multicolumn{7}{|c|}{ Multivariate Diagnostics } \\
\hline \multirow[t]{2}{*}{ Hosking (10) } & 23.197 & & 17.191 & & & 24.307 \\
\hline & [0.971] & & [0.998] & & & [0.958] \\
\hline \multirow[t]{2}{*}{ Li-McLeod (10) } & 23.265 & & 17.512 & & & 24.426 \\
\hline & [0.971] & & {$[0.998]$} & & & {$[0.956]$} \\
\hline
\end{tabular}

Notes: (a), (b) and (c) denote the statistical significance at the 1\%, 5\% and $10 \%$ level

Overall, our results reveal that gold is a hedge across stocks in general and a safe haven in times of market stress. In this respect, investors can benefit from increasing gold prices when stock markets downturn. For bonds, we posit that the gold is a hedge on average and not a safe haven in the crisis period.

The findings of the paper highlight the significance of proper hedging strategies and the value of including gold to optimize portfolios. 
Figure 3

Plots of Time-varying Correlations between Gold and Bonds
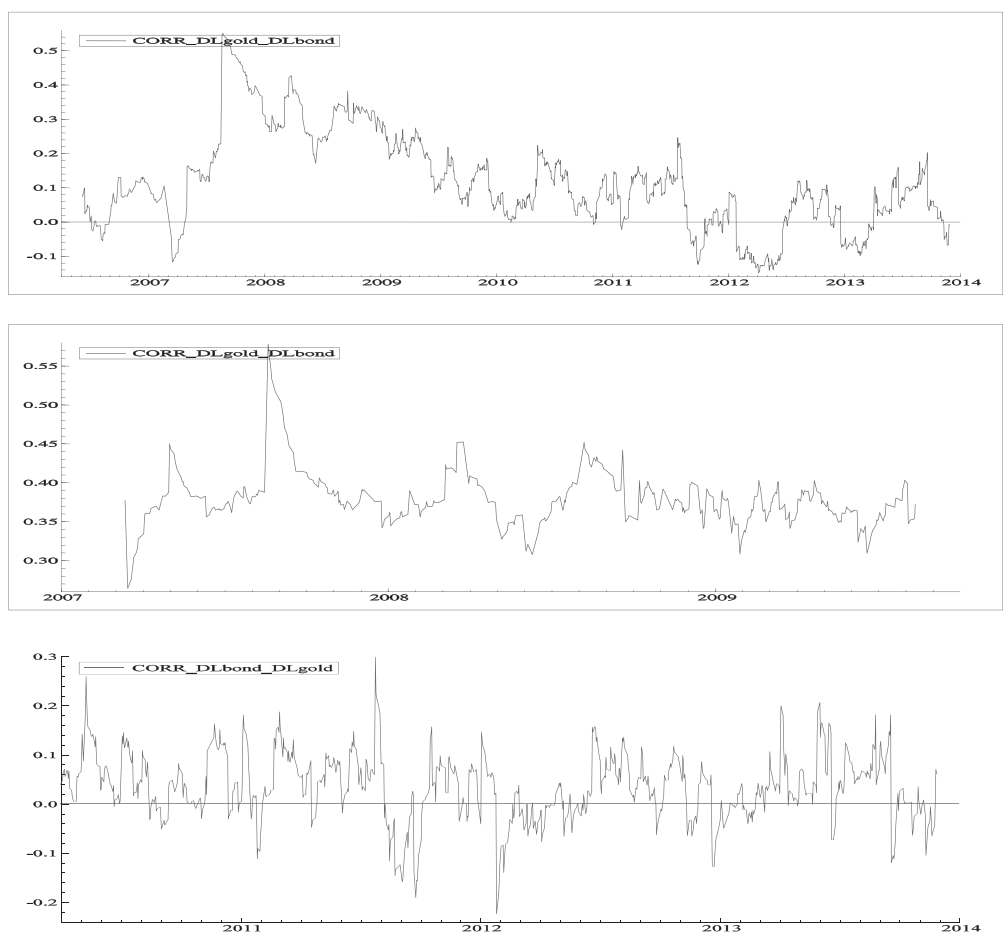

\section{Conclusion}

In this paper, we investigate time-varying correlations between the pairs of gold-stocks and gold-bonds, focusing on the safe haven and hedging properties of gold in Turkish financial markets. We utilize DCC- GARCH $(1,1)$ model which has two steps of analyses consisting univariate GARCH and time-varying conditional correlation modeling. Our univariate GARCH model results denote that current conditional volatility is significantly affected by past news and volatilities for all the assets considered. Following Baur and Lucey (2010) to assess whether gold is a safe haven for the two traditional asset classes, we hypothesize that gold is a hedge (diversifier) if the gold and the asset class are uncorrelated or negatively correlated (positive but not perfectly correlated) on average. On the other hand, it is a safe haven if the correlations are negative in times of financial distress. In the multivariate context, we elaborate the hedging property of gold for both stocks and bonds on average. However, gold does not act as a diversifier in Turkish financial markets because it is not positively and not perfectively correlated with stocks and bonds in general. Our results also indicate that gold is a safe haven for stocks during market turmoil, but we do not empirically document the fact that gold acts as a safe haven for bonds in Turkey. In light of these findings, gold can be assessed as 
a quality asset. Therefore, the inclusion of gold in a stock portfolio will reduce losses at times of market collapses and increase the portfolio efficiency. At normal times, gold will act as a hedge across both bond and stock portfolios. Our findings are of significance for investors and portfolio managers in optimizing the risk-return tradeoff in portfolio rebalancing.

\section{References}

Baker, S.A. and Van Tassel, R.C. (1985). "Forecasting the Price of Gold: A Fundamentalist Approach,” Atlantic Economic Journal, 13(4): 43-51.

Barisheff, N. (2006), "Portfolio Diversification with Gold, Silver and Platinum Bullion," Working Paper, The Alternative Investment Management Association (AIMA).

Baur, D. and Lucey, B.M. (2006). "Flight-to-quality or Contagion? An Empirical Analysis of Stock-bond Correlations," Institute for International Integration Studies Discussion Paper, Trinity College, Dublin.

Baur, D.G. and McDermott, T.K. (2010). "Is Gold a Safe Haven? International Evidence," Journal of Banking and Finance, 34(8), 1886-1898.

Beckmann, J. and Czudaj, R. (2013). "Gold as an Inflation Hedge in a Time-varying Coefficient Framework," The North American Journal of Economics and Finance, 24: 208-222.

Blose, L.E. (1996). "Gold Price Risk and the Returns on Gold Mutual Funds," Journal of Economics and Business, 48(5): 499-513.

Bollerslev, T. (1990). "Modelling the Coherence in Short-run Nominal Exchange Rates: A Multivariate Generalized ARCH Model," The Review of Economics and Statistics, 72: 498-505.

Cai, J., Cheung, Y.L., and Wong, M. (2001). "What moves the gold market?," Journal of Futures Markets, 21(3): 257-278.

Capie, F., Mills, T.C., and Wood, G. (2005). "Gold as a Hedge against the Dollar," Journal of International Financial Markets, Institutions and Money, 15(4: 343-352.

Chua, J H., Sick, G., and Woodward, R. S. (1990). "Diversifying with gold stocks," Financial Analysts Journal, 46(4): 76-79.

Conover, C.M., Jensen, G.R., Johnson, R.R,. and Mercer, J.M. (2007), "Can Precious Metals Make Your Portfolio Shine?," Journal of Investing, 18(1), 75-86.

Connolly, R., Stivers, C., and Sun, L. (2005). "Stock Market Uncertainty and the Stock-bond Return Relation," Journal of Financial and Quantitative Analysis, 40(01): 161-194.

Engle, R. (2002). "Dynamic Conditional Correlation: A Simple Class of Multivariate Generalized Autoregressive Conditional Heteroskedasticity Models," Journal of Business and Economic Statistics, 20(3): 339-350.

Faff, R. and Chan, H. (1998). "A Multifactor Model of Gold Industry Stock Returns: Evidence from the Australian Equity Market," Applied Financial Economics, 8(1), 21-28.

Fortune, N.J. (1988). "The Inflation Rate of the Price of Gold, Expected Prices and Interest Rates," Journal of Macroeconomics, 9(1), 71-82.

Gilmore, C.G., McManus, G.M. and Sharma, R. (2009). "The Dynamics of Gold Prices, Gold Mining Stock Prices and Stock Market Prices Comovements," Research in Applied Economics, 1(1): 1-19. 
Hartmann, P., Straetmans, S., and Devries, C. (2001). “Asset Market Linkages in Crisis Periods," Working Paper No. 71, European Central Bank.

Hillier D., Fraper, P., and Faff, R. (2006), "Do Precious Metals Shine? An Investment Perspective," Financial Analysts Journal, 62(2): 98-106.

Hoang, T.H. (2011, May). "Gold Quoted at Paris and the Diversification of French Portfolios from 2004 to 2009," in International Conference of the French Finance Association (AFFI).

Hood, M. and Malik, F. (2013). "Is Gold the Best Hedge and a Safe Haven under Changing Stock Market Volatility?" Review of Financial Economics, 22(2): 47-52.

İbrahim, M.H., and Baharom, A.H. (2011). "The Role of Gold in Financial Investment: A Malaysian Perspective," International Center for Education in Islamic Finance.

Jaffe, J.F. (1989). "Gold and Gold Stocks as Investments for Institutional Portfolios.” Financial Analysts Journal, 53-59.

Jaiswal, U.K. and Voronina, V. (2011). "Relationship between Gold and Stocks: Empirical Evidence from BRICs," Master Thesis, Umea School of Business, Umea University.

Kaufmann, T.D. and Winters, R A. (1989). "The Price of Gold: A Simple Model," Resources Policy, 15(4): 309-313.

Koutsoyiannis, A. (1983). "A Short-run Pricing Model for a Speculative Asset, Tested with Data from the Gold Bullion Market," Applied Economics, 15(5), 563-581.

Kutan, A.M. and Aksoy, T. (2004). "Public Information Arrival and Gold Market Returns in Emerging Markets: Evidence from the Istanbul Gold Exchange," Scientific Journal of Administrative Development, 2: 13-26.

Lawrence, C. (2003). "Why is Gold Different from Other Assets? An Empirical Investigation," London, UK: The World Gold Council.

Longin, F.and Solnik, B. (1995). "Is the Correlation in International Equity Returns Constant: 19601990?," Journal of International Money and Finance, 14(1): 3-26.

Lucey, B., Tully, E., and Poti, V. (2006). "International Portfolio Formation, Skewness and the Role of Gold," Frontiers in Finance and Economics, 3(1): 49-67.

McCown, J. and Zimmerman, J. (2006). "Is Gold a Zero-beta Asset? Analysis of the Investment Potential of Precious Metals," Meinders School of Business, Oklahoma City University (July 24, 2006).

McDonald, J.G. and Solnick, B.H. (1977). "Valuation and Strategy for Gold Stocks," The Journal of Portfolio Management, 3(3), 29-33.

Michaud, R., Michaud, R., and Pulvermacher, K. (2006). "Gold as a Strategic Asset," World Gold Council, London.

Mishra, P.K., Das, J.R., and Mishra, S.K. (2010). "Gold Price Volatility and Stock Market Returns in India," American Journal of Scientific Research, 9: 47-55.

Ratner, M. and Klein, S. (2008), “The Portfolio Implications of Gold Investment," The Journal of Investing, 17(1): 77-87.

Sjaastad, L.A. and Scacciavillani, F. (1996). "The Price of Gold and the Exchange Rate," Journal of International Money and Finance, 15(6): 879-897.

Sherman, E.J. (1982). "Gold: A Conservative, Prudent Diversifier," The Journal of Portfolio Management, 8(3): 21-27. 
Smith, G. (2001). "The Price of Gold and Stock Price Indices for the United States," The World Gold Council, 8: 1-16.

Smith, G. (2002). "London Gold Prices and Stock Price Indices in Europe and Japan," World Gold Council, 1-30.

Sumner, S., Johnson, R., and Soenen, L. (2010). "Spillover Effects among Gold, Stocks, and Bonds," Journal of Centrum Cathedra, 3(2). 106-120.

Tully, E. and Lucey, B.M. (2007). “A Power GARCH Examination of the Gold Market,” Research in International Business and Finance, 21(2), 316-325.

Wang, K.M., Lee, Y.M., and Thi, T.B.N. (2011). "Time and Place where Gold Acts as an Inflation Hedge: An Application of Long-run and Short-run Threshold Models," Economic Modelling, 28(3): 806-819.

Worthington, A.C. and Pahlavani, M. (2007). "Gold Investment as an Inflationary Hedge: Cointegration Evidence with Allowance for Endogenous Structural Breaks," Applied Financial Economics Letters, 3(4), 259-262.

Wozniak, R. (2008). "Gold as a Strategic Asset for UK Investors," London: World Gold Council.

Ziaei, S.M. (2012). "Effects of Gold Price on Equity, Bond and Domestic Credit: Evidence from ASEAN+ 3," Procedia-Social and Behavioral Sciences, 40: 341-346. 
